\title{
The Interpersonal Factors Affecting the Introduction to English Literature Lecturers' Politeness Strategy
}

\author{
Teofilus Natanael \& Adventina Putranti \\ teofilus.natanael@gmail.com \& putranti@usd.ac.id \\ Department of English Letters, Universitas Sanata Dharma
}

\begin{abstract}
Politeness strategy is always associated with a group of people with different social backgrounds. In their conversations, some people tend to apply different politeness strategy depending on the social status of the people whom they are talking to. One of the situations where the politeness strategy takes place is in a classroom. The way of a certain lecturer, as the one who has authority, delivers his or her instructions represents a particular politeness strategy. By considering the subject and the context, classroom situation is selected as the data source in analyzing politeness strategy and the factors that influence it. Apparently, social distance and power are the factors triggering each lecturer to apply different types of politeness strategy.
\end{abstract}

Keywords: Politeness strategy, the factors, Power, Social distance

\section{Introduction}

People in this world communicate with each other. This communication is one of their natural behaviors as a social creature. John Hubley (1993) states that communication involves the transfer between people of information including ideas, emotions, knowledge and skills (p. 45). Conversation, as one form of communication, has varied purposes from one situation to others. It depends on the participant or situation of the conversation.

Sometimes, the conversation can happen formally when the situation is formal such as in an office and school. The language between the participants is formal because of their different status and setting, like what happens between a manager and his or her staff. The staff, known as the person in a corporate hierarchy whose position is lower, talks politely to his or her boss in order to show his or her respect.
Unlike that hierarchical relation between a boss and an employee, the relation, for example, between friends is more informal. They speak casual language in their conversation. The interlocutors talk to each other without any significant consideration of a certain degree of formality and do not have to apply more formal language because of the closeness of their relationship.

The relation of each participant, then, affects the use of different expressionseither formal or less formal. In a conversation, these differences in expressions are related to politeness. Based on Yule (1996), politeness is a way to show awareness of another person's public face (p.60). In other words, politeness is a condition when someone applies a certain language expression by considering his or her interlocutors. Furthermore, the purpose of this research is to figure out the politeness strategies, related to the factors influencing each strategy in a lecturer-students relationship applied by a group of lecturers at Universitas Sanata Dharma. 
It is interesting to conduct a study observing something in real life where people, in this case lecturers, really apply politeness strategy in their daily interaction, especially with their students. The lecturer-student relationship is often understood as an asymmetrical relationship. However there are several lecturers who apparently tend to be relatively close to their students. The lecturers can possibly place themselves as a friend or learning assistant for the students. By becoming so, the students tend to be more active to participate in the discussion since the learning-teaching style today is more student-oriented. It is in line with the statement from Maypole and Davies (2001) that student-centered learning is defined as a fact that knowledge is produced when students are the key initiators and architects of their own learning and knowledge making rather than passive 'vessels' who receive the transmission of knowledge from 'expert' teachers (as cited in Barraket, 2005, p. 65).

To be more specific, this linguistic study selects "Introduction to English Literature" lecturers as its sample. Moreover, this subject also turns out to be crucial for the students since it becomes the fundamental element for them to, further, study literature in the English Letters Department. Through the perspective of politeness, this research aims to reveal how the lecturers, examined by means of the language expressions that they use in their instructions, put themselves in their relationship with the students.

\section{Politeness}

During the interaction, people encounter different people from different age, gender, and social class. This condition affects the use of language by the speaker. For example is the language of parents and children. Parents may order their children to behave or be quiet. They usually use certain expression such as: "Behave!" and "Be quiet!" On the other hand, the language of a teacher and students is different. When a student asks for permission to his teacher, he or she will say, "Excuse me, Ma'am, may I wash my hand?" These differences, then, are called politeness strategy. According to Yule (1996), politeness is defined as a way to show awareness of another person's public self-image (p. 60). To support Yule's statement, Cruse (2006, p. 131) states that politeness is a matter of minimizing the negative effects of what one says on the feelings of others and maximizing the positive effects.

\section{Face}

The main concept of politeness approach is face. Yule (1996, p. 60) defines face as a public self-image of a person. It refers to that emotional and social sense of self that everyone has and expects everyone else to recognize. In order to reach successful social interaction, people should be aware of another one's face.

In line with Yule's definition, face is the positive social value a person effectively claims for himself by the line others assume he or she has taken during a particular contact (Goffman as cited in Holtgraves, 2002, p. 39). In Holtgraves' book, 'face' is divided into two parts. First, negative face is the right to get freedom of action and freedom from imposition, while, positive face, the second one, is the need to be appreciated by others, and to maintain a positive self-image (2002, p. 39). For example, when someone asks to get a pen from someone else, if he applies negative face, he says "Could you lend me a pen?" On the other hand, if he wants to show his positive face, he can say, "How about letting me to use your pen?"

In everyday conversation, a person often expects that their public self-image will be respected or the so-called face wants. Yule (1998, p. 61) explains that if the speaker says something to lessen the possible threat from another's face, it is called a face saving act.

\section{a. Face-Threatening Act (FTA)}

The threat that is given to another individual's self-image is called FaceThreatening Act or FTA (Yule, 1996, p. 61). This act avoids the freedom of actions (negative face) and states someone's wish to be wanted by others (positive face). In an attempt to avoid FTA, the interlocutors use 
specific strategies to minimize the threat according to a rational assessment of the participants' face risk.

\section{Off Record}

Off record (indirect) takes some pressure off of the speaker. The utterances in off record are indirectly addressed to the other (Yule, 1996, p. 63). It precises the fact that the meaning of an utterance is interpreted up to the hearer. The FTA performs off record, typically through the deployment of an indirect illocutionary act which has more than one interpretations and, thus, allows presumptive deniability on the part of the speaker. It happens when the intended recipient takes offence at the face threat inherent in the utterance. Brown and Levinson (1987) in Holtgraves' book categorize the off record sub strategies based on Gricean's four maxims, especially the ones that are violated. Firstly, violation of the quality maxim results in sarcastic irony, metaphor, rhetorical question. violation of the manner maxim, as the second one, causes euphemisms and vagueness. Third, violation of quantity maxim can result in understatement or overstatement. While the last one, the violation of relation maxim can occur in variety condition (as cited in Holtgraves, 2002, p. 44)

In conclusion, a person can do off record and leave it up to the addressee to decide how to interpret it. The hearer cannot know with certainty that a hint has been broached; the speaker can credibly claim an alternative interpretation. Here, the threat to face is very high. Inviting conversational implicature and being vague or ambiguous are the sub strategies of off record.

\section{On Record}

In contrast to off record statement, on record means expressing something directly toward the speaker (Yule, 1996, p. 63)

\section{i. Bald on Record}

In this strategy, FTA is performed. Bald on record represents attachment to Grice's maxims and hence, the form is maximally efficient communication (Brown \& Levinson as cited in Holtgraves. 2002, p. 42). To do so "baldly" entails phrasing it in direct and honest terms with no attempt to soften the face-threatening thrust. The bald on record does nothing to minimize threats to the hearer's face. Here, there is no attempt to acknowledge what the hearer's face wants. This strategy usually uses imperative form.

\section{ii. Face Saving Act}

The utterances or actions to lessen the threat of another's face are called face saving act, A face saving act which is oriented to the person's negative face is called negative politeness. Whereas, a face saving act concerned with the person's positive faceone tending to show solidarity and emphasizes that both speakers want the same thing and they have a common goal-is called positive politeness (Yule, 1996, p. 62).

\section{Positive Politeness}

Positive face refers to every individual's basic desire for their public self-image to be engaged, ratified, and appreciated by others. The FTA is done by utilizing strategies which are oriented towards the positive face threat received by the hearer. The essence of this strategy is the staking of a claim for some degree of familiarity with one's interlocutor (Holtgraves, 2002, p. 46). The positive politeness shows that the speaker recognizes the hearer has desire to be respected. It also confirms that the relationship is friendly and it expresses group reciprocity. This type of strategy is usually found in some groups of friends or where the people in a social situation know each other fairly well.

Here, the threat to face is relatively low. It usually tries to minimize the distance between them by expressing friendly statement and solid interest in the hearer's needs. According to Brown and Levinson, there are three strategies which are included in positive politeness. They are claiming common ground, conveying that the speaker and the hearer are co-operators, and fulfilling the hearer's want for something.

\section{Negative Politeness}

The negative politeness also recognizes the hearer's negative face (desire for autonomy) (Holtgraves, 2002, p. 44). However, it also admits that the speaker is 
imposing on the hearer. This is the most common and linguistically diverse strategy. Negative polite constructions contain negative face by demonstrating distance and wariness. The negative politeness focuses on minimizing the imposition by attempting to soften it.

The sub strategies of negative politeness include being conventionally indirect. It can be performed by questioning or asserting felicity condition underlying the act. Thus, to request another to shut a door, one can say, "Will you shut the door?", "Can you shut the door?", "I want you to shut the door", and so on.

Negative politeness also can be done through not presuming or assuming anything regarding the hearer's belief or desire. The primary means for this strategy is through the use of hedges. Here are two examples of hedges: "I think abortion is wrong, by the way..." and "I'm sorry to bring this up, but..."

The other sub-strategy also involves an attempt to lessen threat. It includes not only conventional indirectness, but also conveying of pessimism. "Would you open the window?" as well as "You don't have any spare paper don't you?" are the examples of the sub-strategy.

The next strategy is to communicate explicitly that one does not want to weight upon the other. For example, "I don't want to bother you, but..." this strategy shows that a person does not want to be a burden for others. It shows one's respect to another.

The final sub-strategy of negative politeness is to simply go on record as incurring a debt (e.g., "I'd be eternally grateful for your help"). Holtgraves (2002) states that this strategy gives directness to the speaker, but the speaker gives more emphasis on his or her feeling (pp. 44-46).

\section{b. No Face Threatening Act (No FTA)}

Here, the speakers entirely avoid performing the FTA, totally avoiding threat to another's face. Speakers choose this strategy when they estimate the threat to another's face is extremely high. In other words, this strategy results in silence. The speaker tends not to say anything (Yule, 1996, p. 62)

For example, there is someone who wants to borrow a lawnmower from his neighbor. If he does not know his neighbor, he may decide to choose the negative pole of rational decision (not to do the FTA at all), which logically result in never borrowing the lawnmower at all. Of course, if he is desperate, he can secretly "borrow" the lawnmower without asking and without the addressee knowing. In the end, this strategy is showing someone's intention to do something by him or herself without saying anything to others.

Figure 1. Politeness strategy from Brown and Levinson (1987, p. 316) 


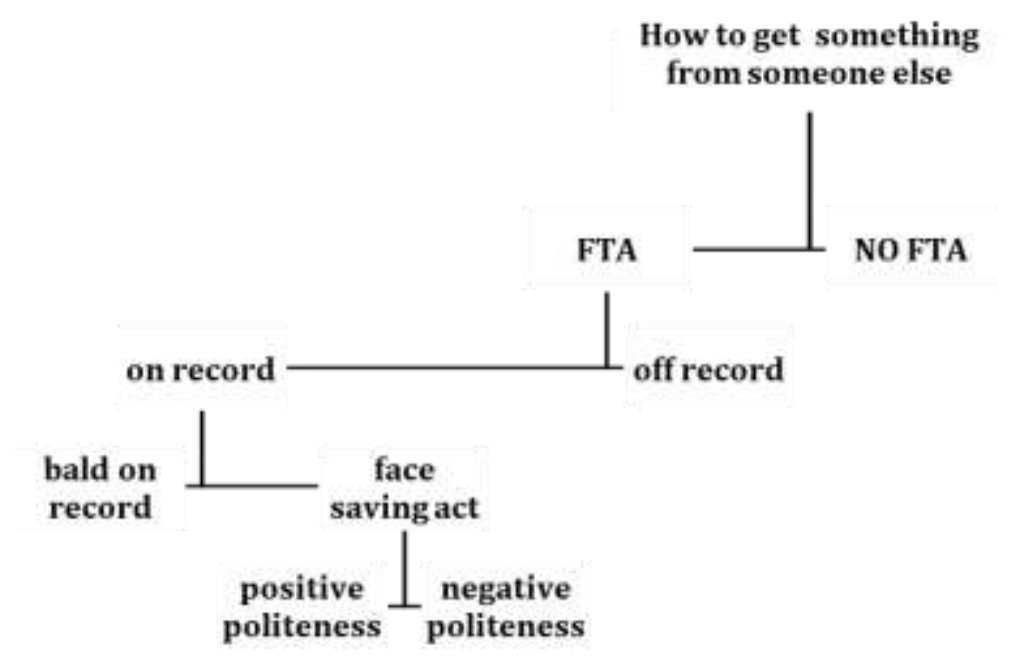

\section{The Interpersonal-Determinant Politeness}

Brown and Levinson (1987) state that the seriousness of an FTA which may affect choice of politeness strategies involves the interpersonal-determinant factors (p. 319). In addition, it is known from their theory as well that there are three categories of interpersonal determinant factors. First is the social distance, second one is the relative power and third, the last one is the absolute ranking of impositions in certain culture as briefly described below.

\section{a. Social Distance}

Brown and Levinson say that distance is a symmetrical social dimension of similarity or difference within which speakers and hearers stand for the purpose of an act (1987, p.320). As it is known that the communication between friends is more informal since there is no great social distance. While on the contrary, the higher social distance triggers higher degree of politeness of the participant.

Yule (1996) classifies it into two different strategies. The tendency to use positive politeness form, emphasizing closeness between speaker and hearer, this can be seen as a solidarity strategy. While the tendency to use negative politeness form, emphasizing the hearer's freedom which is seen as deference strategy. It is impersonal as if nothing is shared between the interlocutors. This strategy is also called formal politeness (p. 66).

\section{b. Relative Power}

Brown and Levinson (1987) classify the sources of power into two. They are material control (over economic distribution and physical force) and metaphysical power (over the action of others) (p. 321). This explanation can be clearly seen in the given example by Brown and Levinson (1987).

When a boss asks for permission to his or her employee, he or she just says, "Mind if I smoke?" or to be direct (bald on record). On the contrary, when the employee asks for permission to the boss, he or she applies high degree of politeness by saying, "Excuse me, Sir, would it be alright if I smoke?" (as cited in Holtgraves, 2002, p. 80).

\section{c. Absolute ranking of imposition in the certain culture}

Impositions can still situationally vary in value, according to Brown and Levinson (1987, p. 321). Brown and Levinson categorize impositions two ranks called rank of order of imposition requiring services and rank of order of impositions requiring goods (including information). These impositions cause FTAs. The greater the FTAs, the greater the imposition of the act is. This is when the speaker uses highly standard politeness strategies in his or her speaking. 


\section{Politeness Strategies Applied by the Lecturers of Introduction to English Literature Subject}

This part presents that the lecturers apply several types of politeness strategies in delivering their instructions. The writer finds out that there are four types of politeness strategies applied. They are bald on record, positive, negative politeness strategy, and off record. In total, there are thirty-one utterances of politeness strategies in giving instructions. In order to gain better comprehension of the data that the researcher has got in this research, the writer provides a table so that it becomes more wellorganized and understandable. The table presents the types of politeness found in the lecturers' instructions, the occurrences or how many times a certain type is applied, and the percentage of each type's application.

Table 1.

Politeness Strategies Applied by the Lecturers of Introduction to English Literature

\begin{tabular}{|c|l|c|c|}
\hline No & \multicolumn{1}{|c|}{ Type of politeness } & Occurrence & Percentage \\
\hline 1 & Bald on record & 8 & $26 \%$ \\
\hline 2 & Positive politeness strategy & 15 & $48 \%$ \\
\hline 3 & Negative politeness strategy & 7 & $23 \%$ \\
\hline 4 & Off record & 1 & $3 \%$ \\
\hline & Total & 31 & $100 \%$ \\
\hline
\end{tabular}

As stated earlier that there are four types of politeness strategies applied by the lecturers. Eight of them are bald on record strategy or $26 \%$ in percentage. For positive politeness strategy, it appears fifteen times$48 \%$ out of $100 \%$ in percentage. Seven utterances contain negative politeness strategy or $23 \%$ in percentage. While for the other one is classified as off record strategy that in other words, it is $3 \%$ in percentage. However, firstly, the writer analyzes each of the strategy in order to get a close understanding of each strategy.

\section{Bald on Record}

Bald on record is categorized as the least polite strategy (completely absence of politeness). This strategy aims to reach maximum efficiency of communication (Holtgraves, 2002. p. 42). In other words, this type is applied when a person or speaker wants to directly convey his or her point to the interlocutor in order to optimize their communication efficiency as mentioned before. They do not have to add some hedges before they really deliver their intention; they just directly say what they really want to say. In this research, there are two utterances containing bald on record. Here are some of the following situations when the lecturers apply bald on record strategy.

\section{8/55/Lecturer A/bld/power}

\section{Lecturer A:}

All right, even when we talk about Uncle James, it is very serious by the end. He was really scared, you know scared, but you know the laugh. Why? Why? (...) Yeah it is against what happen in our daily experience right. That is why so we, we have found the reason. Next, is the point clear? Yeah, 
so sense of proportion has been violated. And then next, back to uncle. You know his uncle, so what do you think, as I said to you earlier, right? He didn't pretend, he was really scared, you know. From the expression on his face, he was really scared. (...) We burst into laughter, right? Why? Why? Earlier we talked about sense of humor. Now, we are trying to see other characters. Why?

Students: (Silent)

Lecturer A:

Yeah, still silent. Two minutes with your neighbor. Discuss it again. Discuss it again with your neighbors for two until five minutes. So, why we couldn't help laughing, why?

Lecturer $A$, in his utterances of giving instruction, applies bald on record strategy. This strategy comes up after he asks the students the same question for more than one time, but his students still do not even join into the discussion-Lecturer A's question remains unanswered. The silence of his students triggers the lecturer to give a direct instruction by finally applying bald on record in order to gain direct result from his students. He delivers his instructions directly and without any ambiguity. Bald on record strategy, which takes form of an instruction or imperative sentence during the discussion, actually represents the directness of an instruction.

In addition, the word "please" in a bald on record strategy can also be used as a mitigation device to soften the demand. It is stated at this example below.

\section{7/83/Lecturer C /bld/power}

\section{Lecturer C:}

It always starts with "when" (...). Okay, up to this point, do you have any question? All right, if you have no question, then I guess it is already over for today. So, tomorrow we will meet again, please, bring the short story.

Students: Okay.

Lecturer C :

Thank you so much.

\section{Positive Politeness Strategy}

The positive politeness basically shows the fact that the speaker recognizes the hearer's desire to be respected. It also confirms that the relationship is friendly and it expresses reciprocity. in other words, this positive politeness strategy shows intimacy between the interlocutor and the speaker as it happens in a group of friends or a group of people knowing each other well. In this research, there are fifteen utterances of giving instructions that contain positive politeness strategy. The analysis of this strategy is represented by several examples from the lecturers' instructions.

\section{1/1/Lecturer B /pstiv/distance}

\section{Lecturer B:}

So, these are two stories. A Jury of Her Peers by Glaspell and the second short story is Sweet Potato Pie. So, we're going to read this one first: Sweet Potato Pie. A Jury of Her Peers is short story version of Susan Glaspell's Trifle. So, after she wrote the drama Trifle, the play Trifle, she wrote the short story version entitled A Jury of Her Peers. Later on, we will try to identify the difference that you can find as readers how the short story differs from the play version, okay? But, before we go to that one, we are going to read Sweet Potato Pie. (Deliver the short story to the students). Is ten minutes enough for you, students? Is ten minutes enough for you? All right I'm going to let you read for $\mathbf{1 0}$ minutes. After that, we are going to read the other. We're going to take turn with this.

Students:

(Students read the short story) 
In the conversations above, Lecturer B shows the sense of togetherness. The word "we" indicates that they have the same purpose and same goal in that class. The focus of the discussion is not only the students, but also the lecturer. The lecturer participates and involves herself in the discussion. Based on Brown and Levinson (1987), she applies the second sub-strategy from positive politeness strategy. It is to claim the association by virtue of the fact that speaker and hearer are, in some sense, are cooperator (Brown and Levinson as cited in Holtgraves, 2002, p. 47).

The other inclusive term "let's", since "let's" actually involves both "you and I", also becomes the marker of this second substrategy of positive politeness. Lecturer A counts himself in so that he makes his relationship with the students in line.

\section{2/1/Lecturer A/pstiv/distance}

\section{Lecturer A:}

Now let's focus on the two plays. Yeah, the two plays. Jessica Agustia. Jessica? So where is she? Come late? Okay, Amelia Indiravani? Amelia? Yeah, do you still remember the tittle of the plays? Even you have forgotten too? Yeah, the tittle of the plays? You do not remember of them? How come?!

\section{Students: (Mumbling)}

Brown and Levinson (1987) have mentioned that the speaker and the hearer are, in some sense, co-operators. Lecturer A, as well as Lecturer B, use the word "let's" and "we" in their instructions to show this sense. Basically, the words "we" and "let's" are known to give the sense of togetherness in an action and inclusivity. In this case, it shows the fact that the lecturers apply positive politeness strategy. The participants of that conversation are not just limited to either the speaker or the hearer only, but both of them are all involved. Betty (1996) states that "let's" means I have suggestion for us (p. 169). It conveys that, as if the action is being done by both of them.
Positive politeness strategy can also be indicated by sharing a certain common ground. Lecturer B, in her teaching, also applies this sub-strategy. These two utterances below show Lecturer B's intention to build the same understanding about Buddy's characterization with her students before trying to start the discussion.

\section{2/133/Lecturer B/pstiv/distance}

\section{Lecturer B:}

Okay, because your brother is going to look like a porter and you do not want that to happen, okay... So, now from this occurrences, can you find the character, the characterization of Buddy...? He used to be a poor boy and he was finally able to overcome the obstacles by becoming a professor, right? He visited Charlie, his big brother, and he still ate sweet potato pie and it was not a fancy food for professor, but he ate that anyway. He was angry when his brother told his students that he was a friend of himself, not as a brother. So, what kind of characterization? Okay? Yeah?

\section{Student 1: Down to earth?}

\section{Lecturer B: Down to earth? Okay...}

In this case, Lecturer B does the so-called grounding. It is accomplished, according to Brown and Levinson, by conveying the idea that the speaker and the hearer are connected by something in common (1987, p. 46). From the two examples, Lecturer B makes the common ground by simplifying it-she encourages her students to imagine the things happening in their real lives and then make it as the illustration of the story. Lecturer B tries to build the same point of view with the students. In the end, the grounding finally enables her students to feel the condition and comprehend the story better.

Besides the common grounding discussed in the preceding paragraph, positive politeness strategy also can be seen from the in-group markers. This notion, then, is supported also by Brown and Levinson (1987). They mention that group membership 
may be emphasized by using various in-group markers such as familiar address terms such as mate, pal, luv, and guys (p. 46). However, in order to support the theory proposed by Brown and Levinson (1987), the observer also cites a quotation from Yuka's article entitled "Positive Politeness Strategies in Oral Communication" (2009). She, as an associate professor in Takasaki City University, states that some of the typical examples of positive politeness strategy are complimenting, joking, responding emphatically, and using nicknames (p. 60). The use of familiar ingroup markers are shown below.

\section{6/29/Lecturer B /pstiv/distance}

Lecturer B:

Okay, thank you. Vero. Mentioned something about poverty here. All right, if you notice the subject, the subject of the story is..., it has something to do with poverty. All right, I need one more student to explore more about this subject: poverty. How does the writerexplore about the Buddy's poverty in the short story? Whom do you choose, Vero?

Vero: Dira

\section{Lecturer B:}

Dira, poverty. The subject of poverty in the story.

In the utterance, Lecturer $\mathrm{B}$ gives instructions to her student, named Dira, to explain more about poverty in the story. In doing it, Lecturer B calls his names by the first name directly. In this case, calling her student' nicknames signifies that she applies positive politeness strategy in her instruction with the usage of familiar verbal marker.

In addition, in the next utterance, she applies "guys" when she instructs her students to stop. This also indicates another familiar address term. These findings are proven to be in line with the statements stated by Brown and Levinson (1987) in their book and Yuka in her article.

\section{7/33/Lecturer B/pstiv/distance}

Lecturer B:

Okay, guys, can you stop there for a while and explore what does shared cropper mean? What does shared cropper mean? What kind of farmer is a shared cropper. Shared crop?

\section{Dira:}

They have farm, but it appears they only harvest from the owner's farm and divided the...

\section{Lecturer B: Yeah, the crop.}

\section{Negative Politeness Strategy}

Negative politeness strategy is performed when the speaker considers the negative face of the hearer. In other words, the speakers try to give freedom toward their their hearer. Therefore, this gives an effect on the indirectness of giving an instruction. There are five sub-strategies proposed by Brown and Levinson (1987). In this research, the writer finds three sub-strategies from seven utterances applying the negative politeness strategy. Four of them are selected to be discussed in this part to represent the applied strategy.

The most-applied sub-strategy of negative politeness is the indirect one. There are several features which mark this strategy. First, it can be performed by asserting or questioning the felicity condition underlining requests. Second, the utterance containing the request-based form (Holtgraves, 2002, p. 45). Below are some utterances when the lecturers apply the negative politeness substrategy by being indirect when conveying their instructions.

\section{2/31/Lecturer C/ngtiv/distance}

Lecturer C:

(...) now, then, you can compare that why are the speaker calls 16 as sweet, but then, 70 age, it might be not sweet. What is the opposite of sweet? Bitter 70 age or hard 70 age, so whatever they called means anything. But, the speaker starts to think of that age 
when he starts to lose a bit by bit the sweetness of life. All right, now you have question number two and then also question number three-A for stanza two, yeah. I would like you, then, to discuss those questions, question number two, then question number three- $B$, and then question number five-A. Okay, number two, number three-B, and number five, then I would like some of you offer your opinion. Okay, good.

Students: (Students do discussion).

Observing the example above, the researcher finds that in delivering her instruction, the lecturer applies mitigation device to decrease the effect of face threatening act caused by direct instruction. In this case, rather than using the expression "I want you to...", she tends to apply "I would like you to..." which is generally considered to be more polite.

The other negative politeness strategy is by showing the sense of pessimism. It is shown in the utterance below.

\section{4/33/Lecturer C/ngtiv/distance}

\section{Lecturer C:}

(...) Maybe I will ask some opinion from (read the attendance list), Aulia.... Yeeah, why these drastic changes in time do you think?

\section{Aulia:}

To show that the relationship between grandfather... and the grand daughter is like the relationship between two years and three years old child... hehehe because child, children only....

First of all, according to Ariel (2008), as an utterance of a sentence, pragmatics aspect gives the implicit meaning of a sentence, while grammar aspects display the explicit meaning of it (p. 433). It can be concluded that pragmatics and structure are related to one another. This relation can be seen through the politeness phenomena.
Seen from the grammatical aspect, the sense of pessimism in the instruction above is portrayed by the usage of "maybe" and "will". The word "maybe" has only less than 50\% sure of certainty (Azar, 1999, p. 176) and the word "will" is applied when the speaker makes a prediction in the future (Azar, 1999, p.52). The pessimism is also categorized as the sub-trategy of negative politeness stated by Brown and Levinson (as cited in Holtgraves, 2002, p. 45).

Another sub-strategy found in this research is involving attempts to lessen threat toward the interlocutor. In this sub-strategy, the speaker not only adds the sense of pessimism in his or her indirect instruction or request, but he or she also shows doubtfulness in their request or instruction. The use of subjunctive is one way to do this strategy.

\section{9/59/Lecturer A/ngtiv/distance}

\section{Lecturer A:}

All right. So, have you got the answer now? Come on, Albet. So why? What has made us burst into laughter when we go to that scene, yeah, come on?

\section{Student: (Silent)}

\section{Lecturer A:}

\section{So would you please return the attendance list, please? Attendance list. Yeah, why?}

Lecturer A indirectly gives the instruction to his students to bring back the attendance list. Then, he applies the subjunctive "would you..." that goes together with the word "please". This form gives the sense of freedom to the hearer which, then, becomes the main point of negative politeness strategy. In addition, Lecturer $\mathrm{A}$ does not want to threat his students' negative face, he conveys his point indirectly and is pessimistic. If, for example, the student cannot make it because of a certain reason, Lecturer A does not mind, too. This leads Lecturer A to choose negative politeness strategy in giving his instruction. The phrase "would you..." adds the sense of freedom to the hearer which is actually the 
essence of negative politeness strategy. However, although the core of it is the sense of the hearer's freedom, in this case, the student does not have any other options, but to do what his or her lecturer asks for. Departing from that fact, this research is directed to another discussion that is explained later in the next section.

\section{Off Record}

Off record is categorized as the most polite strategy. When people apply this strategy, they avoid threaten the hearer's face. Because of the ambiguity in the meaning, the utterance can finally result in having double or even multiple meanings. "I work in such a jail!" is one of the examples. The person saying this sentence can be understood as a person who works in a building that the doors are totally locked during the office hours. Another perspective may be metaphorically interpreted as a condition in which the worker is somehow under pressure since his or her boss stresses him or her out. In brief, the meaning of a certain expression applying off record strategy can be interpreted up to the hearer. This strategy adopts the Gricean's maxims for categorizing the types (Brown and Levinson's as cited at Holtgraves, 2002, p. 43). It is grouped based on what maxim is violated, such as maxim quality, quantity, relation, and manner. The researcher finds one utterance of off record strategy coming from Lecturer A. He applies this strategy when he gives instruction to the students to answer his question.

\section{7/45 Lecturer A/ofrd/distance}

\section{Lecturer A:}

(...) I think in drama, there is no narrator, right? In drama, there is no narrator. It is different from the short story we read the other day, why, come on. You are sastra students, you know, you should be able to explain it to you friend studying in different department. Why? Come on. What's amusing? All the characters are serious on the stage, but the audience, you know, yeah, keep laughing. Yeah? Yeah, come on, come on. Why? Sorry, silence is not golden anymore.
Students: Wesss... (Amazed).

Lecturer A: So, did you hear me?

Students: Yes. (Together)

In this case, Lecturer A violates maxim of quality through his statement "silence is not golden anymore" which is a form of sarcastic metaphor as another kind of off record strategy. People know that the right proverb is "silence is golden", but in this case, Lecturer A talks conversely to create a sarcastic expression. This expression is created to give an instruction to the students which equals to, "Come on, say something and be active," for example. In other words, Lecturer A states the phrase because he is triggered by his students' silence and so it also may represent his annoyance at his students. Overall, he states that metaphorical expression in order to satirize his students.

\section{The Factors Influencing Lecturers' Politeness Strategy in Giving Instructions}

Lecturer-student relationship is an asymmetrical relationship. This phenomenon is also noticed by Cazden (1988). She finds that in typical classroom, teachers have the right to speak at any time and to any person; they can fill any silence or interrupt any speaker; they can speak to a student anywhere in the room and in any volume or tone of voice. No one has any right to object (p. 54). It can be proven from the fact that teacher or lecturer always becomes the one who controls the conversation or any decision inside the class. In other words, the lecturer is a person who has an authority upon his or her students. Moreover, there are many different ways for each lecturer to interact with their students, for example lecturers may use question, command, request, and information along their interaction with the students.

Giving instructions, in this case, can be used as the framework to analyze how the lecturers behave toward their students. The instructions of each lecturer become the representation of their intention to construct a certain type of relationship with the 
students. Tsui states that instruction is usually given by a person who has the right to get the addressee to comply or obey. This right is usually due to the power or authority that he has over the latter. In addition, the right also may be due to the work setting in which who is to do what is clearly defined (1995, p.129).

In this research, the writer finds that each lecturer applies a certain type of politeness strategy in delivering his or her instructions. The strategies are categorized in the range of the most direct instruction, which is bald on record, to the most indirect type that is off record strategy. By means of interpersonal determinants of politeness proposed by Brown and Levinson, the writer analyzes each lecturer's intention thoroughly.

The interpersonal determinant of politeness depends on three variables: the degree of imposition, the social distance, and the relative power of the hearer over the speaker. Based on the theory, the greater the realized face threat of the to-be performed act (the weightiness of the threat), the greater the probability that a speaker will opt for a more polite strategy (Holtgraves, 2002, p. 47). The factors that influence the lecturers' politeness strategies are shown below.

\section{Social Distance}

Distance is a symmetrical social dimension of similarity or difference within which speaker and hearer stand for the purpose of this act. The reflex of social closeness is, generally, noticed by giving and receiving of positive face (Brown and Levinson, 1987, pp. 320-321).

In thirteen utterances of giving instructions, Lecturer B applies positive politeness strategy. Based on the perspective of interpersonal determinant politeness proposed by Brown and Levinson (1987), the greater the realized face threat of the to-be performed act (the weightiness of the threat), the greater the probability that a speaker will opt for a more polite strategy. Due to the fact that Lecturer B, as the one having authority in the class, she has the right to speak directly, especially when instructing. However, the result of this research shows that Lecturer B prefers to apply positive politeness strategy rather than bald on record which is in the form of direct instruction.

Positive politeness strategy emphasizes on claiming for some degree of familiarity. In this case, Lecturer B tries to decrease the distance by decreasing the weightiness of her direct act. This strategy implies that Lecturer $\mathrm{B}$ has an intention to decrease her distance with the students. This is in line with Yule (1996) who states that the tendency to use positive politeness form, emphasizing closeness between speaker and hearer, can be seen as a solidarity strategy (p. 66). In order to construct more detailed explanation about Lecturer B's intention, here are some utterances from Lecturer B's instructions.

\section{1/1/Lecturer B /pstiv/distance}

\section{Lecturer B: \\ All right, I'm going to let you read for 10 minutes.}

In this first utterance, Lecturer B instructs her students to read for 10 minutes. She shows her intention to lessen the weightiness of her direct act through the positive politeness strategy. The phrase "going to" adds the sense of optimism which is one of the characteristic of politeness strategy. Azar states that "going to" is used when someone has an exact plan in the future (1999, p. 52). The utterance proves that Lecturer B avoids to use her power through the direct instructions or bald on record strategy. Her attempt to decrease the distance is also reflected by the application of familiar addressee terms which are commonly used by a group of people with close relationship. It is captured in this utterance.

\section{7/33/Lecturer B /pstiv/distance}

Lecturer B:

Okay, guys, can you stop there for a while and explore what does shared cropper mean? 
The utterance represents how Lecturer B positions herself in the relationship. As the one with authority, actually she does not need to instruct her students by using their nick name or familiar verbal marker. She is permitted to do it directly without any hedges, but in fact, in her lecture, she applies this strategy related to her attempt in decreasing the distance. This assumption is also strengthened by the use of certain pronouns showing the fact that Lecturer B involves herself in the instructions.

\section{8/61/Lecturer B /distance}

\section{Lecturer B: \\ We're going to juxtapose or, you know, menyejajarkan, juxtapose the setting of Buddy's apartment, Buddy's place with Charlie's apartment. Can you find the one?}

The word "we" in these utterances highlight the participants. In an asymmetrical relationship like this, the relation is clear between the commander and the doer. The action is always done by the ones commanded so that it affects the form of sentence used by the speaker. Asymmetrical relationship lets the speaker to use direct expression, that in instruction, it is identical with imperative sentence ("Do x!"). Conversely, in this case, Lecturer B removes the boundary by saying "we" when she instructs her students and so she involves herself into the activity.

The last characteristic that displays Lecturer B's attempt in decreasing her distance toward the students is grounding. Grounding is a strategy when someone tells about background knowledge toward his or her hearer in order to have the same perspective or understanding on the discussed topic. This strategy helps the speaker to establish the fact that they share the same interest upon something.

\section{0/91/Lecturer B /pstiv/distance}

Lecturer B:

Then, you had a sister or a brother who was a cab driver and brought that black plastic bag for you, behind you. Behind. Not with you, but behind. You feel odd, right, but why? Can you tell me why?

However, in addition, the datum proves that Lecturer A also has an intention to become closer with his students by applying positive strategy.

\section{2/1/Lecturer A/pstiv/distance \\ Lecturer A:}

Now let's focus on the two plays.

The word "let's" emphasizes the sense of togetherness. "Let's" or "let us" emphasizes that the doer is "us", not only limited to the speaker or hearer, but both of them. Betty states that "let's" means I have suggestion for us (p. 169). It conveys that, as if the action is being done by both of them.

In the end, it can be said that the lecturer having intention to decrease his or her social distance is reducing the weightiness of his or her act in giving instructions. The lecturer reduces his or her weightiness through the positive politeness strategy.

On the other hand, the researcher also finds the intention to make a distance with the students through the application of negative politeness strategy. Negative politeness strategy is a strategy that appreciates the hearer's negative face, desire for autonomy (Holtgraves, 2002, p. 44). The tendency to use negative politeness form, emphasizing the hearer's freedom which is seen as deference strategy. It is impersonal as if nothing is shared between the interlocutors (Yule 1996, p. 66). This strategy is considered as a polite strategy related to the indirectness. Yule conveys that indirect speech acts are generally associated with greater politeness (1996, p. 56). From the perspective of interpersonal determinant politeness, her intention to be more indirect to her students when giving instruction is caused by social distance. As the one with authority or power, her strategy to apply indirect speech act or negative politeness in giving instructions is increasing the weightiness of an act. The increasing of the weightiness affects the increasing of social distance (Holtgraves, 2002, p. 48). 
In Lecturer C's instructions, the researcher finds the negative politeness strategy. From seven utterances of her instructions, four of them are negative politeness strategy, specifically being conventionally indirect. Brown and Levinson (1987) state that conventional indirect forms can be performed by questioning such as: "Can you shut the door?" and "Would you shut the door?" In other ways, it can also be performed by asserting felicity conditions in the form of performative sentence such as: "I want you to shut the door" and "I would like you to shut the door" (as the more polite form of "want") (as cited in Holtgraves, 2002, p. $44)$.

The type of Lecturer C's instructions indicates that she determines to apply conventional indirect form by asserting the felicity conditions underlying the acts. Below are the utterances of instructions given by Lecturer C.

\section{1/19/Lecturer C/ngtiv/distance}

\section{Lecturer C:}

Now, I'd like you to look at your handout. Then, you have the poem "Pollen". The tittle of the poem is "Pollen" and Pollen is a proper name.

Lecturer $\mathrm{C}$ delivers her instructions by using performative sentences in the polite form. Although being the one with the authority, this strategy implies that she still shows respect toward her students. Related to the interpersonal determinant politeness theory, Lecturer C's utterances are affected by the variable of distance. It is proven by her indirect utterances in giving instructions. The indirectness of an utterance is always equal with politeness. The increase of weightiness (that people would likely be polite) is associated with the increasing distance between the speaker and hearer (Brown and Levinson, 1987). However, in the other one of her utterances, Lecturer $\mathrm{C}$ also applies conventional indirect expression, but in the form of questioning.

\section{6/81/Lecturer C/ngtiv/distance}

Lecturer C :
Can you give me an example of things that are repeated in the first stanza? Anything repeated there?

Once again, in this utterance, Lecturer $\mathrm{C}$ tends to be indirect. This indirectness proves that Lecturer $C$ does not want to threat her students' face by being direct in giving instructions. Additionally, Lecturer $\mathrm{C}$ is also conveying the sense of pessimism in another instruction as shown below.

\section{4/33/Lecturer C /ngtiv/distance Lecturer C:}

Maybe I will ask some opinion from... Aulia (while looking at the attendance list).

The sense of pessimism is portrayed by the usage of "maybe" and "will". As discussed in the previous section, the word "maybe" has only less than $50 \%$ sure of certainty (Azar, 1999, p. 176) and the word "will" is applied when the speaker makes a prediction in the future (Azar, 1999, p.52). It means that the prediction itself can be either wrong or right. The pessimism is also categorized as the sub strategy of negative politeness stated by Brown and Levinson (as cited in Holtgraves, 2002, p. 45).

Lecturer A, in this research, also applies negative politeness strategy when he asks his students to return the attendance list. He uses subjunctive in order to convey the pessimism regarding the appropriateness of the act to be performed (Holrgraves, 2002, p. 45)

\section{9/59/Lecturer A/ngtiv/distance Lecturer A : \\ Would you please return the attendance list? Please, the attendance list.}

By applying this strategy, actually Lecturer A, who has an authority, tries to appreciate his students. The negative politeness indicates that Lecturer $\mathrm{A}$ has awareness toward his students' negative face. So, despite being direct, Lecturer A applies negative politeness strategy to be more polite. Another politeness strategy considered to be 
the most polite one is applied by Lecturer A. It is called off record strategy.

\section{7/45 Lecturer A /ofrd/distance Lecturer A:}

Yeah? Yeah, come on, come on, why. Sorry, silence is not golden anymore.

He presents the sarcastic expression by uttering the phrase "silence is not golden anymore". The form of its indirectness indicates politeness. To support it, Yule ever states that indirect speech acts are generally associated with greater politeness (1996, p. 56). This indirectness, then, is contrast with his authority as the one who has right to speak directly upon his students.

In this research, the researcher does not find any condition related to the imposition rank which affects certain politeness strategy. Since the lecturers have greater authority than their students, the power variable in this case is settled. So, the one that affects the lecturers' instructions is distance variable and in brief, the positive politeness strategy represents the lecturer's intention to build closer relationship with the students. The reflex of social closeness is, generally, noticed by giving and receiving of positive face (Brown and Levinson, 1999, pp. 320-321). While negative politeness and off record strategy represent a social distance between the interlocutors. Based on the perspective of interpersonal determinant politeness proposed by Brown and Levinson (1987), the greater the realized face threat of the to-be performed act (the weightiness of the threat), the greater the probability that a speaker will opt for a more polite strategy which is negative politeness strategy.

\section{Relative Power}

Bald on record, based on the politeness strategy of Brown and Levinson (1987), is classified as the least polite strategy or the complete absence of politeness (Holtgraves, 2002, p. 42). The strategy represents maximally efficient of communication, Yule (1996) adds that bald on record is associated with speech events where the speaker assumes that he or she has power over the other. Tsui, in line with Yule (1996), states that instruction is usually given by a person who has the right to get the addressee to comply or obey. This right is usually due to the power or authority that he has over the latter. In addition, the right also may be due to the work setting in which who is to do what is clearly defined (1995, p.129).

In this research, the writer finds that Lecturer A has an intention to emphasize his position as the one who has authority through his direct instructions or bald on record strategy. Based on Brown and Levinson (1987), it is classified as metaphysical power (over the action of others) (p. 321). These occurrences can be observed by the application of interpersonal determinant theory proposed by Brown and Levinson stating that politeness strategy depends on three variables-they are power, social distance, and imposition rank. Thus, speaker's power over hearer increase, the weightiness off the face threatening act diminishes (Brown and Levinson, 1987. p. 322). In addition, Brown and levinson (1987) states that positive politeness is assumed to be less polite than negative politeness. It signs closeness between the interlocutors, while negative politeness indicates a polite attitude (as cited in Holtgraves, 2002, p. 43). From the theory, it is proven that Lecturer $\mathrm{A}$, as the speaker, has an intention to show power to his students. In most of his utterances of giving instructions, Lecturer A does not either increase his weightiness of an act by being polite in the form of negative politeness strategy or decrease it by applying friendly strategy (positive politeness strategy). In fact, Lecturer A tends to apply the bald on record strategy in order to show his authority. The directness of his instruction points out the maximum efficiency of his order which is frequently used in the formal context by the one who has authority. His students can interpret his instruction directly without having any ambiguity.

Unlike the other two lecturers having been discussed, Lecturer A applies bald on record more frequently when he gives instructions. From his eleven utterances in giving instructions, seven utterances are categorized as bald on record. The utterances 
as well as the detail explanation from each strategy is presented as shown below.

\section{1/1/Lecturer A/bld/power}

Lecturer A:

Now, let me... Attention, please! Thank you.

Throughout his lecturing session, Lecturer A also tries to make his instructions more polite. In this utterance, Lecturer A adds the word "please" to make his instruction more polite. Yule states that "please" is used to soften the demand and it is called mitigation device (1996, p. 63). In addition, Yule also emphasizes that bald on record are associated with speech events where the speaker assumes that he or she has power over other (1996, p. 64). The form of his utterances points out that the instructions are delivered in the form of imperative as captured in these utterances.

\section{$\underline{3 / 15 / \text { Lecturer A/bld/power }}$}

\section{Lecturer A:}

No coaching, don't tell him. Don't tell him, no coaching. All right, you fail.

He applies an imperative form of an instruction. It is a sentence that contains a verb directly followed by an object.

Lecturer $\mathrm{C}$, in this research, also applies the mitigation device in one of her instruction.
ISSN: 1410-5691 (print); 2580-5078 (online)

\section{7/83/Lecturer C /bld/power}

Lecturer C :

So, tomorrow we will meet again. Please bring the short story.

In this utterance, Lecturer $\mathrm{C}$ states directly toward her students to bring the material for next discussion in her class. The strategy indicates that, as a lecturer, she has an authority or power to instruct her students to do something. This is due to the fact that an instruction is usually given by the one who has authority.

After all of this discussion, it can be concluded that Lecturer A has an intention for showing his power. It can be seen from the use of bald on record strategy that dominates his utterances. He avoids ambiguity by saying his intention straight to the point in order to receive direct result from his students. His intention is neither to increase nor to decrease the weightiness of the instructions act. It reveals that Lecturer A tends to apply Grice's maxim of quantity, being as informative as required (Holtgraves, 2002, p. 24).

To sum up the result of this research, below the table containing the number of utterances from each lecturer and the interpersonal determinants are presented.

Table 2. Number of Utterances

\begin{tabular}{|c|c|c|c|}
\hline $\begin{array}{c}\text { Lecturer/ } \\
\text { Politeness strategy }\end{array}$ & Lecturer B & Lecturer C & Lecturer A \\
\hline Positive & 13 & - & 2 \\
\hline Negative & - & 6 & 1 \\
\hline Bald on Record & - & 1 & 7 \\
\hline Off record & - & - & 1 \\
\hline
\end{tabular}

Table 3. Interpersonal Determinant

\begin{tabular}{|c|c|c|c|}
\hline $\begin{array}{c}\text { Lecturer/ } \\
\text { Variable }\end{array}$ & Lecturer B & Lecturer C & Lecturer A \\
\hline Power & & & $\sqrt{ }$ \\
\hline Distance (+/-) & $\sqrt{(-)}$ & $\sqrt{ }(+)$ & \\
\hline
\end{tabular}


From the tables above, it can be seen that each politeness strategy is identical with certain interpersonal-determinant politeness in the context of asymmetrical relationship. The lecturer who applies positive politeness strategy tend to decrease the distance $(\sqrt{ }(-))$, while the one who applies more negative politeness strategies in giving instruction, increase the distance $(\sqrt{ }(+))$. In addition, the lecturer with domination of bald on record in his instructions emphasizes his power toward the students.

\section{Conclusion}

From the discussion above, it can be concluded that the lecturers of Introduction to English Literature apply different politeness strategy depending on their intention in building relationship with their students. Lecturer B, who tends to be more informal or friendlier, applies positive politeness strategy the most. Meanwhile, the other two lecturers of this subject apply more negative politeness and bald on record strategy to deliver their instructions which emphasize the social distance and different power between the lecturers and students. Lecturer $\mathrm{C}$ tends to use negative politeness strategy toward her students to show distance. On the other hand, Lecturer A applies bald on record strategy which indicates authority.

\section{References}

Ariel, Mira. (2008). Pragmatics and Grammar. In Zielinska D. (Ed.) (2010). The Series Cambridge Textbooks in Linguistics (pp. 433-434). Cambridge: Cambridge University Press..

Azar, Betty Schrampfer. (1999). Understanding and Using English Grammar Third Edition. New York: Longman.
Barraket, Joe. (2005). Teaching Research Method Using a Student-Centred Approach? Critical Reflections on Practice. Journal of University Teaching \& Learning Practice. 2(2) 62-74. Retrieved from

https://files.eric.ed.gov/fulltext/EJ1059 434.pdf (on 5 June 2018).

Brown, P., \& Levinson, S. C. (1987). Politeness: Some universals in language usage [Reprint]. In A. Jaworski, \& N. Coupland. (2006), The discourse reader (pp. 311323). London: Routledge.

Cazden, Courtney B. (1988). Classroom Discourse: The Language of Teaching and Learning. Pourtsmouth: Heinemann.

Crossman, Ashley. (2018, April 1). Understanding Purposive Sampling: An Overview of the Method and Its Applications. Retrieved from https://www.thoughtco.com/purposivesampling-3026727 (on 12 June 2018)

Cruse, Alan. (2006). A Glossary of Semantics and Pragmatics. Edinburgh: Edinburgh University Press.

Hasmi, Mifta. (2013). A Pragmatic Analysis of Politeness Strategies Reflected in Nanny Mcphee Movie (Undergraduate Thesis). Universitas Negeri Yogyakarta, Yogyakarta.

Holtgraves, Thomas. (2002). Language as Social Action: Social Psychology and Language Use. Mahwah: Lawrence Erlbaum Associates.

Hubley, John. (1993). Communicating Health. London: Macmillan.

Sanderson, Linda. (1995). Linguistic Contradiction: Power and Politeness in Courtroom Discourse. Technostyle. 12(2) 1-24. Retrieved from http://journals.sfu.ca/cjsdw/index.p hp/cjsdw/article/download/397/37 7 (on 27 May 2018) 
Septiyani, Widanti. (2016). The Use of Brown and Levinson's Politeness strategies by the Main Characters od Bride Wars Movie (Undergraduate Thesis). Universitas Sanata Dharma, Yogyakarta.

Tsui, Amy B. M. (1995). English Conversation. Hong Kong: Oxford University Press.

Yuka, Akutsu. (2009). Positive Politeness Strategies in Oral Communication.

1(52) 59-70. Retrieved from http://www1.tcue.ac.jp/home1/kgakkai/ronsyuu/ronsyuukeisai/52_1/ak utsu.pdf (on 30 May 2018).

Yule,George. (1996). Pragmatics. Hong Kong: Oxford University Press. 